\title{
Acidity, Electric Conductivity, Dissolved Oxygen Total Dissolved Solid and Salinity Profiles of Marine Water in Gaza: Influence of Wastewater Discharge
}

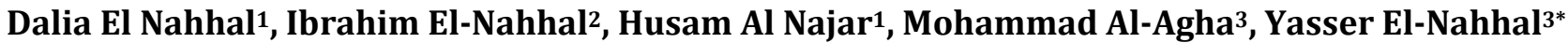 \\ ${ }^{1}$ Faculty of Health Sciences, Islamic University of Gaza, Gaza Strip, Palestine \\ ${ }^{2}$ Université de Toulon, Toulon, France \\ ${ }^{3}$ Department Environment and Earth Science, Faculty Science, Islamic University of Gaza, Gaza Strip, Palestine \\ Email: *y_el_nahhal@hotmail.com
}

How to cite this paper: El Nahhal, D., El-Nahhal, I., Al Najar, H., Al-Agha, M. and El-Nahhal, Y. (2021) Acidity, Electric Conductivity, Dissolved Oxygen Total Dissolved Solid and Salinity Profiles of Marine Water in Gaza: Influence of Wastewater Discharge. American Journal of Analytical Chemistry, 12, 408-428.

https://doi.org/10.4236/ajac.2021.1211025

Received: September 25, 2021

Accepted: November 14, 2021

Published: November 17, 2021

Copyright $\odot 2021$ by author(s) and Scientific Research Publishing Inc. This work is licensed under the Creative Commons Attribution International License (CC BY 4.0).

http://creativecommons.org/licenses/by/4.0/

\begin{abstract}
Effects of wastewater discharge on the coastal area in Gaza strip Palestine are not fully investigated. This study investigated the effect wastewater discharge of the physical and chemical properties of marine water in the coastal area over a period of 2 year. Sea water and sediment samples were collected from about 20 different sites. The water and the sediments were collected wastewater/sea water mixing zone at depth $0,2.5$ and $5 \mathrm{~m}$ water column depth at a direct wastewater discharging pipe line from different location and similarly from other locations. Water temperature $\mathrm{T}$, electric conductivity (EC), dissolved oxygen (DO), $\mathrm{pH}$, total dissolved solid (TDS) and salinity were determined for water samples using field equipment such as $\mathrm{pH}$-meter, DO meter, TDS-/ and EC-meter. On the other hand, $\mathrm{NO}_{3}^{-}, \mathrm{SO}_{4}^{2-}, \mathrm{PO}_{4}^{3-}$ were determined in the laboratory using chemical methods, details are described in materials and method section. Results showed average and standard deviation of T, EC, DO, $\mathrm{pH}$, TDS and salinity were $22.02^{\circ} \mathrm{C} \pm 4.1^{\circ} \mathrm{C}$, EC: $58.41 \pm 4.8$ $\mathrm{ms} / \mathrm{cm}$; DO: $6.96 \pm 1.8 \mathrm{mg} / \mathrm{L}$; pH: $7.69 \pm 0.37$; TDS: $30.51 \pm 3.29$ and salinity $4.39 \pm 0.12(\%)$; whereas, average and standard deviation of $\mathrm{NO}_{3}^{-}$: were 299.8 $\pm 204.1 \mathrm{mg} / \mathrm{L} ; \mathrm{SO}_{4}^{2-}, 5736.9 \pm 817.1$; and $\mathrm{PO}_{4}^{3-}: 164.35 \pm 120.7 \mathrm{mg} / \mathrm{L}$. The measured values indicate significant differences due to high value of standard deviation of some measured parameters. This indicates the influence of wastewater discharge in sea water as shown inside the manuscript in the appropriate section. The study recommends efficient treatment of wastewater and reuses it for agricultural purposes instead of discharging it in sea.
\end{abstract}




\section{Keywords}

Seawater, Wastewater, Marine Sediments, Shellfish, DO, TDS, $\mathrm{NO}_{3}^{-}, \mathrm{SO}_{4}^{2-}$, $\mathrm{PO}_{4}^{3-}$

\section{Introduction}

Seawater physical parameters such as temperature, dissolved oxygen, electric conductivity, and total dissolved salts are important parameters for healthy environment of fish. Partial changes and/or disturbances of these parameters may impact fish lives. Disturbances of physical parameters of the seawater may occur due to discharging raw or partially treated wastewater of different origins by different coastal cities and ships. It has been shown the industrial waste water from coastal cities contained potentially toxic materials [1] [2], fertilizer and pesticide residues [3]. Additionally, shipping and/or fishing activities along the sea shore have been shown to add contaminants to the marine water system [4]. Furthermore, physicochemical parameter of the seawater was affected by atmospheric temperature, rainfall quantity, and other parameters [5]. Discharging of wastewater in Gaza Strip, may contain different types of hazardous chemicals such as pharmaceuticals, pesticides and fertilizers, detergents, heavy metals and dissolved organic compounds. These chemicals may undergo certain reactions in seawater that result in toxic effects to the marine life, changing the physical and the chemical properties of water resulting in changing or disturbing the geochemical cycles of main elements in the sea. However, wastewater is a problem of major concern worldwide. It may contain pesticides residue [6]-[11], pharmaceutical, industrial waste and/or petroleum products [12]. These contaminates may harm aquatic organisms (phytoplankton and zooplankton). It has been shown that pesticide caused damage to marine algae and cyanobacteria [13], harmfully fish [14] and phytotoxicity [15] [16]. It has been reported that wastewater contained considerable levels of heavy metals [17]. Discharging treated waste water to Gabou river in France dramatically changed the concentration of dissolved organic compound [18] [19] [20] and similar result were recorded in the coastal area and marine water in France. Furthermore, five wastewater treatment plants distributed all over the coastal zone ad discharging the wastewater to sea. Almost more than $100,000 \mathrm{~m}^{3} /$ day are discharged to the sea. This large quantity of wastewater neither meets the international nor the Palestinian standards. Effects of discharging waste water to the sea are not fully investigated, additionally the available reports do not providing enough information about the physicochemical properties of the Mediterranean Sea in Gaza. This study investigated the effects of discharging wastewater on the physicochemical properties in the seawater and its effect on geochemical cycles of carbon, nitrogen, sulfur and phosphorus. 


\section{Material and Methods}

All materials used in the analytical determination of nitrate sulfate and phosphates were HPLC grade, purchased from Sigma Aldrich in Tel Aviv via local commercial representative in Gaza. The coastal zone of Gaza strip was subdivided into two subsections. Each section includes 8 sites for monitoring and sampling. The nombres of waste water pipe line that discharge wastewater directly to the sea was counted and presented in Figure 1. Only five pipe lines discharge waste water directly to the sea. These pipe lines are marked with red arrow in the map.

The investigated sites are: Rafah 2, Rafah, Khan Younis, Aquaculture, Khan Younis fish fresh, Khan Younis mixing zone, Dair Albalah S, Dair Albalah N, Gaza fish production, Wadi Gaza 1, Wadi Gaza, Shakh Ejjleen, Sea Port baisin, Sea port out, Sea port out, Sea port, Abu Saif, Abu hassera, Baghdad, Abu Ameera, Ebad Arahman, Kaldi. Mathaf, Sudania and Waha.

\subsection{Seawater Sampling}

About 192 sea water samples were collected from the tested sites (Figure 2) along the sea shore in Gaza during two years experimental period. Using a rental motor boat, sea water samples were collected from all tested sites using plastics cups. The cups were washed with sea water, about $0.5 \mathrm{~L}$ of sea water was collected from different location in each site and mixed together to form $5 \mathrm{~L}$ then the sea water were mixed together to form a pool of sea water Then $1 \mathrm{~L}$ was taken in plastic bottle and used for physical and chemical analysis [21] [22] [23]. The sample were kept in Ice box and analyzed in the next day.

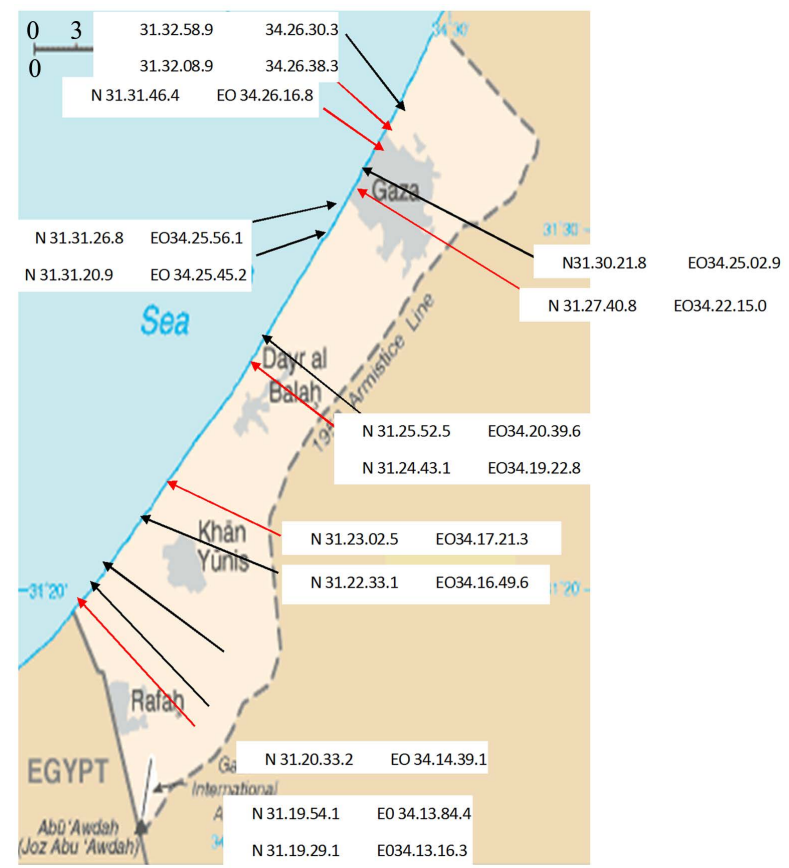

Figure 1. Distribution of sampling sites along coastal zone in Gaza Strip. Red and black arrow indicates treated and raw unofficial wastewater discharge pipe line respectively. 

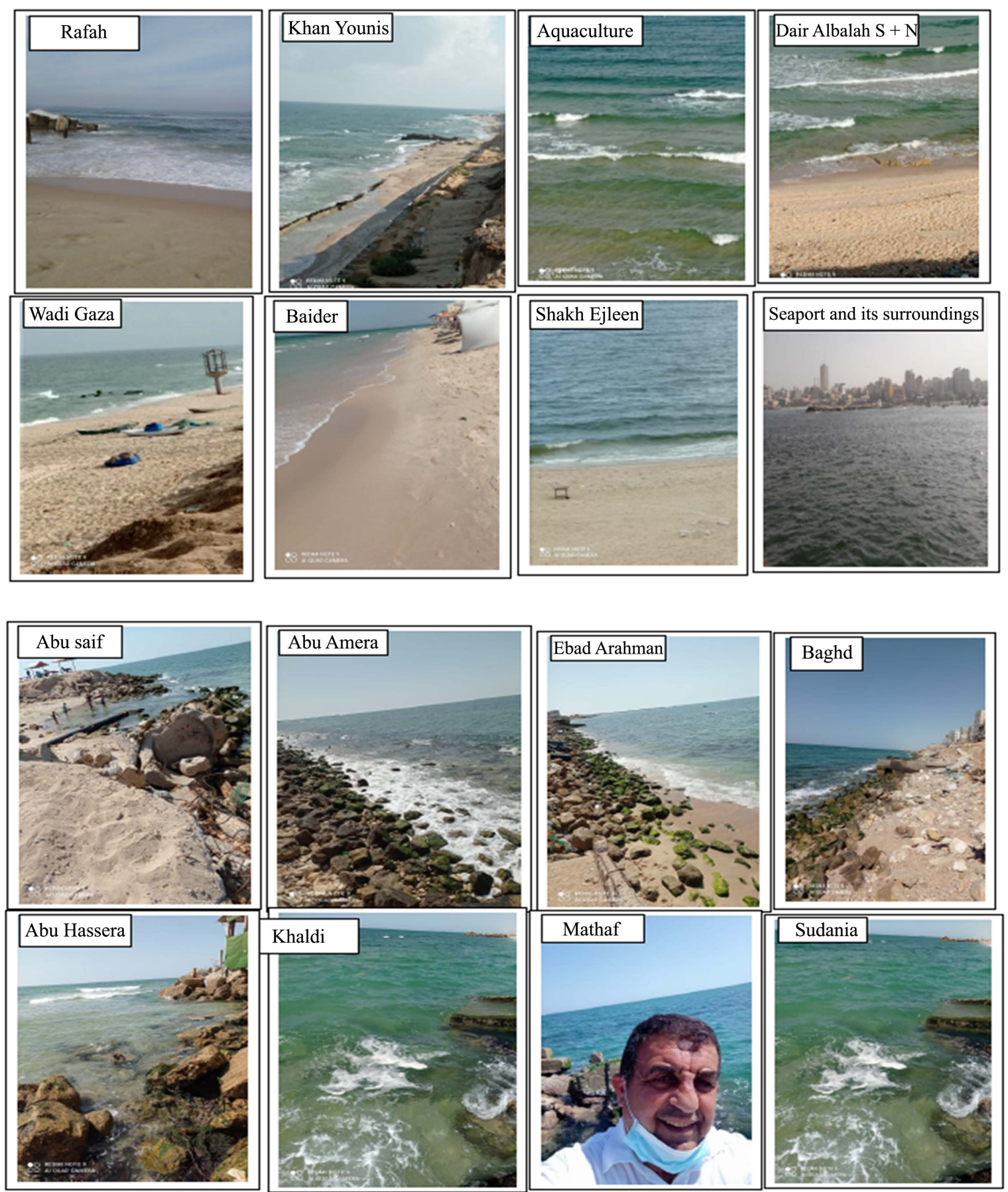

Figure 2. Physical features of the sampling sites along the coastal area in Gaza Strip. This figure includes the photos in the above page.

\subsection{Sediment Collections}

About 28 marine sediment samples were collected from the potentially polluted and non polluted-sites (Figure 2). Three sediment samples were collected from each site at a water level of $2.5 \mathrm{~m}$ with the help of driver. The sediments were air dried for $24 \mathrm{~h}$, sieved through $2 \mathrm{~mm}$ mesh size sieve. The sieved samples were kept in plastic bottles in the laboratory for further analysis. 


\subsection{Determination of Organic Load in Marine Sediments}

Two replicates of $10 \mathrm{~g}$ of air dried sediment from each sample were transferred to Porcelain cups. The cups were transferred to a muffle furnace. Then the furnace was operated at $550^{\circ} \mathrm{C}$ for $12 \mathrm{~h}$ then the system was allowed to call down to the room temperature. Each cup was weighted dry empty, and with sediments. Knowing, the weights of empty cups air dry sediments and the total weight of sediments and cup of the muffle Furnace enable to collect the loss of sediment weight which reflects the organic carbon content. Using the equation below enables the calculation of $\%$ of organic matters

$$
\% \mathrm{OC}=100 * \frac{\mathrm{Wtb}-\mathrm{Wab}}{\mathrm{Wtb}}
$$

where $\mathrm{Wtb}, \mathrm{Wab}$ are the Total weight of cup before and after burning, respectively. Following the procedure describe previously [24].

\subsection{Determination of $\mathrm{pH}, \mathrm{EC}, \mathrm{TDS}$ and DO}

Following previous reports [25] [26], $\mathrm{pH}, \mathrm{EC}$, and TDS were determined using field equipment. Samples were also taken to the laboratory for quality assurance measurements. The temperature was measured immediately on the field using digital and regular thermometers. Water samples were not taken to the laboratory for quality assurance of water temperature measurements to avoid atmospheric heating or cooling possibilities to the samples.

So far, specifications and names of the equipments used in the study are EC-meter (LF 318/Set, Best.-Nr 300,231, made in Germany). A field pH meter electrode (Jenway $3310 \mathrm{UK}$ ), laboratory thermometer, a digital DO meter (HI 8043).

\subsection{Determination of Nitrate Concentration}

The idea behind this method is to undergo nitrification reaction to the salicylic acid using nitrate concentration as a nitrification reagent under acidic media using sulfuric acid to produce a colorless para-nitro-salicylic acid according to Equation (2). Then an alkaline solution $(\mathrm{NaOH}) 6$ molar was added to the system to neutralize the sulfuric acid to produce $\mathrm{Na}_{2} \mathrm{SO}_{4}$. This resulted in the appearance of yellow color. The optical density of yellow color indicates the concentrations of nitrate solution which can be measured at $420 \mu \mathrm{m}$.

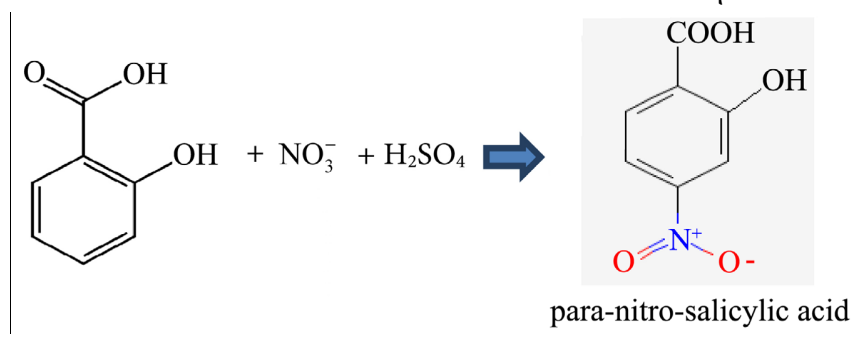

\subsubsection{Preparation of the Standard Solution to Measure Nitrate Concentration}

Step 1. Preparation of the stock solution, in this step about $0.5 \mathrm{~g} \mathrm{NaNO}_{3}$ was 
dissolved in $1 \mathrm{~L}$ of distilled water and form the required stock solution.

Step 2. Preparation of the standard curve solution by series of gradient diluted concentrations $0.1,0.001,0.001,0.0001,0.00001,0.000001 \mathrm{~g} / \mathrm{L}$.

Step 3. Preparation of stock solution of salicylic acid. In this step five gram of salicylic acid was dissolved in $100 \mathrm{ml}$ sulfuric acid under contentious stirring for 4 hours to insure complete solubility of salicylic acid.

Step 4. Five $\mathrm{ml}$ of salicylic acid stock solution was added to a $50 \mathrm{ml}$ round bottom flask containing $3 \mathrm{ml}$ seawater sample/standard solution. The system left for 20 min reaction or until the glass cool down. Because this reaction is an exothermic one.

Step 5. Fifteen $\mathrm{ml} \mathrm{NaOH}$ (6 molar solution) was added to each flask to neutralize the sulfuric acid and to allow the yellow color appear. This procedure was typically applied to the unknown samples.

\subsubsection{Spectroscopic Determination of the Optical Density Nitrate Concentrations}

Nitrate $\left(\mathrm{NO}_{3}^{-}\right)$concentration was determined according to the salicylic acid method, which converts the nitrate concentration under acidic media to the corresponding nitro-salicylic acid with yellow color according to the chemical reactions shown in. The intensity of the yellow color (absorbance) represents the nitrate concentration, and it was determined using a spectrophotometer at $420 \mathrm{~nm}$ according to ref [27].

\subsubsection{Calculation of Nitrate Concentrations}

Regressing the optical density of the standard solution vs concentration enable the formation of a trend line. Then taking the best fit enable generating the suitable equation to determine the unknown samples.

\subsection{Determination of Sulfate}

Sulfate $\left(\mathrm{SO}_{4}^{2-}\right)$ concentration was determined using the turbidity method using barium chloride as previously described in details Ref [24]. In this procedure, 10 $\mathrm{ml}$ of seawater sample was transferred to $50 \mathrm{ml}$ capacity Erlenmeyer flask. Then excess amount of Barium chloride $\left(\mathrm{BCl}_{2}\right)$ were to the flask under magnetic steering to allow the formation of a suspension of barium sulfate (Equation (3)). The reaction time was $5 \pm 0.5 \mathrm{~min}$. The optical density of the suspension was determined at by spectrophotometer at $420 \mathrm{~nm}$. The resulted absorbance was then compared with a curve prepared from a serial dilution of standard sulfate solution reacted with Barium chloride at the same conditions mentioned above.

$$
\text { Sulfateion }+ \text { Bariumion } \rightarrow \text { Bariumsulfate (pricipitate) }
$$

The idea behind adding excess amount of $\mathrm{BCl}_{2}$ is based on the fact that it is soluble in water. We measured the suspended $\mathrm{BSO}_{4}$ which would represent the concentration of sulfate.

Standard solution for sulfate was prepared from pure sulfuric acid by adding $100 \mu \mathrm{l}$ in $1 \mathrm{~L}$ distilled water to form $100 \mathrm{ppm}$ concentration. Then excess amount 
of $\mathrm{BCl}_{2}$ to form the required suspension of $\mathrm{BSO}_{4}$ which then diluted to form the following serial dilution. $\mathrm{M}, \mathrm{M} / 10, \mathrm{M} / 100, \mathrm{M} / 1000$ and $\mathrm{M} / 10,000$ where $\mathrm{M}$ is the concentration of the standard solution (100 ppm).

\subsection{Determination of Phosphate}

Phosphate ion $\left(\mathrm{PO}_{4}^{3-}\right)$ concentration was determined in seawater sample by ascorbic acid method [17] and some modification of Neal et al. [28], our method based on dilution the seawater to $10-20$ times. Then a $10 \mathrm{ml}$ of the diluted sample was transferred to $50 \mathrm{ml}$ capacity Erlenmeyer flask. All the samples were prepared on the same time. The blue color developing solution was added to each flask. The color developing solution contains ammonium molybdate, Antimony, and a ascorbic acid. The idea behind this procedure is to promote the reaction of ammonium molybdate with soluble reactive phosphate ion under acid media to form 1,2-phosphomolybdic acid which is then reduced by ascorbic acid to give a phospho-molybdenum blue complex. Antimony is added to increase the rate of color formation. Then, the optical density of the produced solution was measured at $880 \mathrm{~nm}$.

Details of stock solutions used to prepare the developing blue color are shown below.

1) About $140 \mathrm{ml}$ sulfuric acid $98 \%$ were transferred to were transferred to $1 \mathrm{~L}$ distilled water.

2) About $40 \mathrm{~g}$ ammonium molybdate were dissolved in $1 \mathrm{~L}$ distilled water.

3) About 2.74 g potassium antimony tartrate were dissolved in $1 \mathrm{~L}$ distilled water.

4) About $17.6 \mathrm{~g}$ ascorbic acid were dissolved in $1 \mathrm{~L}$ distilled water.

Preparation of color developing reagent. A mixture reagent consisted of $50 \mathrm{ml}$ of sulfuric acid, $15 \mathrm{ml}$ ammonium molybdate, $5 \mathrm{ml}$ potassium antimony tartrate and $30 \mathrm{ml}$ potassium antimony tartrate was prepared and and mixed together. Then this mixture was used as color developing reagent to determine phosphates in seawater. The procedure of the reaction was as follows.

About $10 \mathrm{ml}$ sample was transferred to around flask bottom then additional $10 \mathrm{ml}$ of blue color developing reagent was added to each flask and left for 30 min to allow the blue color appears. Then the blue color was measured at 880 nm.

Similarly, standard solutions of orthophosphate ion was prepared as mentioned above, then $10 \mathrm{ml}$ of each concentration was transferred to a round bottom flask and $10 \mathrm{ml}$ of blue color developing agent was transferred to each flusk and left to for $30 \mathrm{~min}$.

Then the optical density of blue color was determined at $880 \mathrm{~nm}$ and regressed vs concentration to obtain a linear regarrison mode for determination of the unknown samples.

The tested sites are distributed along the sea shore of Gaza strip. It appears that sites in the southern part of Gaza such as: Rafah 2, Rafah, Khan Younis, Aquaculture, Khan Younis fish fresh, Khan Younis mixing zone, Dair Albalah S, 
Dair Albalah N, Gaza fish production, Wadi Gaza 1, Wadi Gaza, Shakh Ejjleen, are sandy shore Sea Port baisin, Sea port out, Sea port out, Sea port, whereas rock shore included Abu Saif, Abu hassera, Baghdad, Abu Ameera, Ebad Arahman, Kaldi. Mathaf, Sudania and Waha.

\subsection{Statistical Analysis}

Average, standard deviation of each set of parameters were calculated using excel software program version 2016. The data were presented as boxplot to have an over view of each measured parameters in the coastal area. Differences among sites were determined using Reference average and reference standard error and reference confidence intervals as recently developed [29] [30].

Forest plots were presented to illustrate the differences among the tested site. Measurements were repeated 5 times by different sampling in some cases. Standard errors were used to compares means. An overlapping of standard errors indicates no significant different where's no overlapping indicates significant differences of mean, where necessary ANOVA test was used to detect significant differences among treatments. $\mathrm{P}$-values $\leq 0.05$ indicates significant differences

\section{Results}

Measured data of seawater temperature, EC, TDS, DO, and $\mathrm{pH}$ are shown in Table 1.

It can be seen that sea water temperature ranged from $17.1^{\circ} \mathrm{C}-31.07^{\circ} \mathrm{C}$, with an average of 22.07 and a standard deviation of 4.10 . The changes in sea water temperature are due to measurement at different seasons during the experimental period. The electric conductivity (EC) of sea water ranged from $46.82-66.48$ with an average $58.41 \mathrm{~ms} / \mathrm{cm}$. and standard deviation of 4.83 .

The TDS value ranged from 23.15 - 36.14 ppt (part per thousand) with an average value of 30.51 and standard deviation of 3.29. The wide range of TDS value may due to the wastewater discharge to the sea.

The value of DO ranged from $2.09-9.48 \mathrm{mg} / \mathrm{L}$, with an average value 6.96 $\mathrm{mg} / \mathrm{L}$ and standard deviation of 1.75 . These differences may due to wastewater discharge to the sea.

Table 1. Seawater temperature, EC, TDS. DO, $\mathrm{pH}$ and salinity.

\begin{tabular}{ccccccc}
\hline Parameter & Min. & Max. & Median & Average & SD & Range \\
\hline Temp & 17.1 & 31.07 & 20.45 & 22.02 & 4.10 & 13.97 \\
EC & 46.82 & 66.48 & 59.98 & 58.41 & 4.83 & 19.66 \\
TDS & 23.15 & 36.14 & 30.64 & 30.51 & 3.29 & 12.99 \\
DO & 2.09 & 9.48 & 6.92 & 6.96 & 1.75 & 7.39 \\
pH & 7.10 & 8.67 & 7.65 & 7.69 & 0.37 & 1.57 \\
Salinity & 4.10 & 4.6 & 4.40 & 4.39 & 0.12 & 0.50 \\
\hline
\end{tabular}

Min., Max. and SD are minimum, maximum and standard deviation, respectively. 
Value of $\mathrm{pH}$ ranged from $7.10-8.67$ with an average of 7.69 and standard deviation of 0.37 . The changes in the salinity are very narrow.

However, the measured data in Table 1 were presented as boxplots in Figure 4 to test the homogeneity and the outliers of in all tested sites. However, it is well-known that a boxplot is a standard way to displaying the distribution of data based on a five key statistical parameters such as minimum value, first quartile of data ( the minimum value of the box) the median, the $3^{\text {rd }}$ quartile of the data which is the upper line of the box and finally the maximum value. Additionally, the outliers which are the data points presented as a point either below the minimum value or above the maximum value. These values suggest extreme variations of the presented data. For our case we have only 2 boxes having outlies. These are dissolved oxygen and temperature.

The data shown in Figure 3 show the homogeneity of values in some sites and the presence of outliers. Nevertheless, this can be quite normal since the seawater is an open aquatic ecosystem that receives pollutant from different sources.
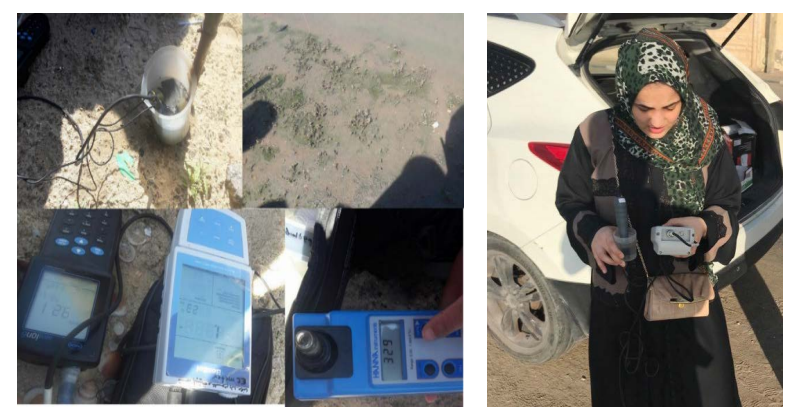

(a)
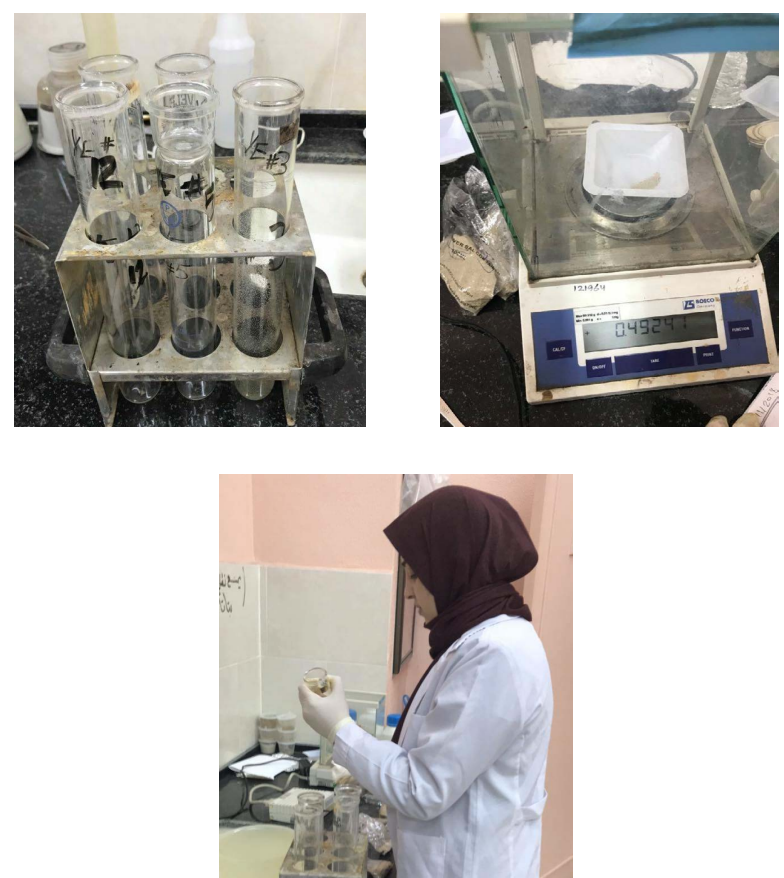

(b)

Figure 3. Field measurements (a) and laboratory experiments (b). 
Moreover, the tested sites are distributed along the coastal area of Gaza strip (45 Km long). It appeared from the field investigation that all site are extremely polluted except Rafah, Deir Al-Balah, Waha and Frusia sites due to low population density and the efficiency of waste water treatment plants in the area.

To determine the differences among sites in each parameter, we calculate the reference average. And used to estimate the relative average of each site and plotted as forest plot. So far, Forest plots of \% oxygen saturation in water are presented in Figure 4.

Concentration of nitrate sulfate and phosphate in the tested sites are presented in Figure 5.

The data shown in Figure 6 show the heterogeneity of nitrate, Sulfate and phosphate values in tested sites. Nevertheless, this can be quite normal since the seawater is an open aquatic ecosystem that receives pollutant from different sources. So far, Table 2 shows the statistical parameters of nitrate, Sulfate and phosphate in the tested sites in Gaza.

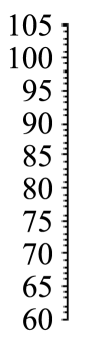

$\llbracket \%$ of oxygen saturation

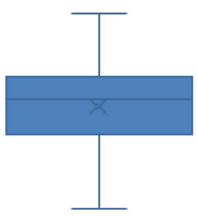

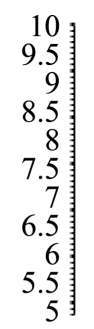

5.5 章
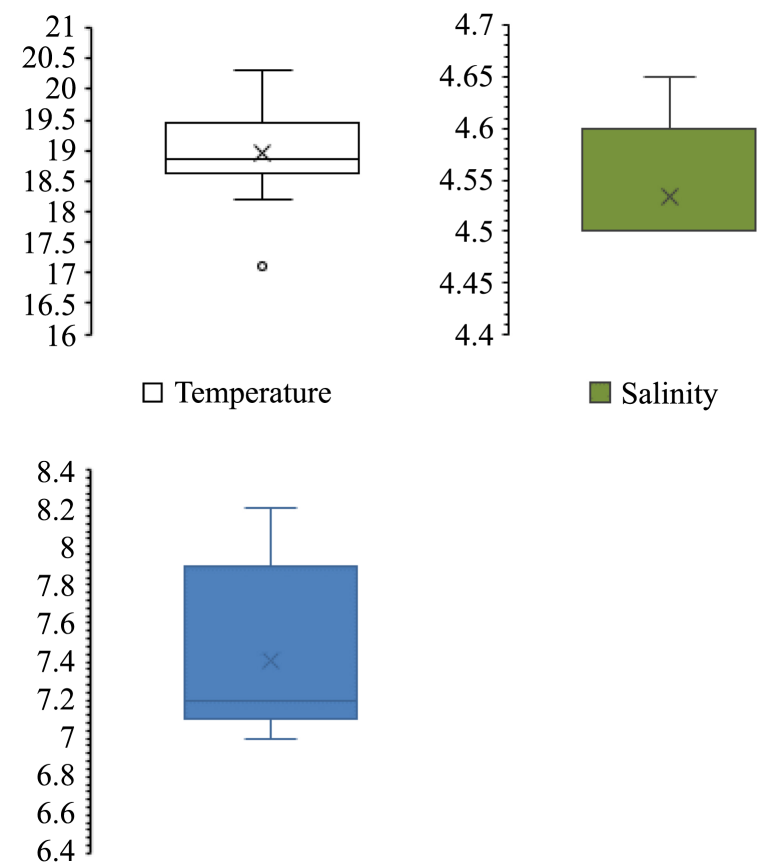

Figure 4. Boxplots of the measured physical parameters in all sites. The presented points outside the box indicate the lowest or highest outliers and $\mathrm{x}$ in the middle of the box indicate the average value whereas the line indicate the median of the measured parameters. 


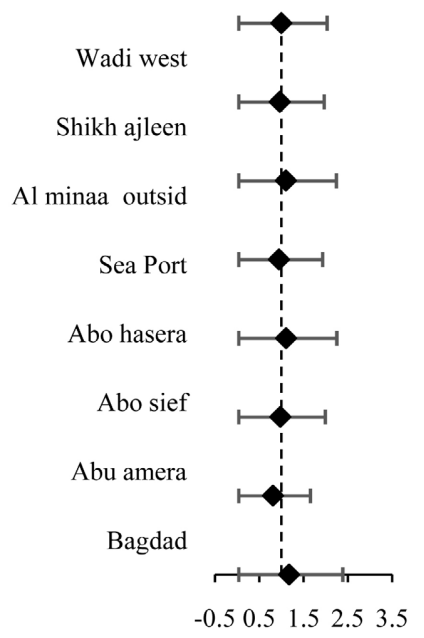

Rel Aver of \% oxygen saluration

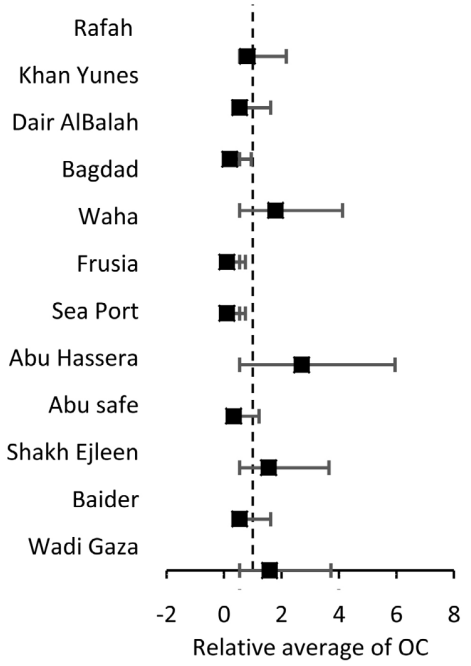

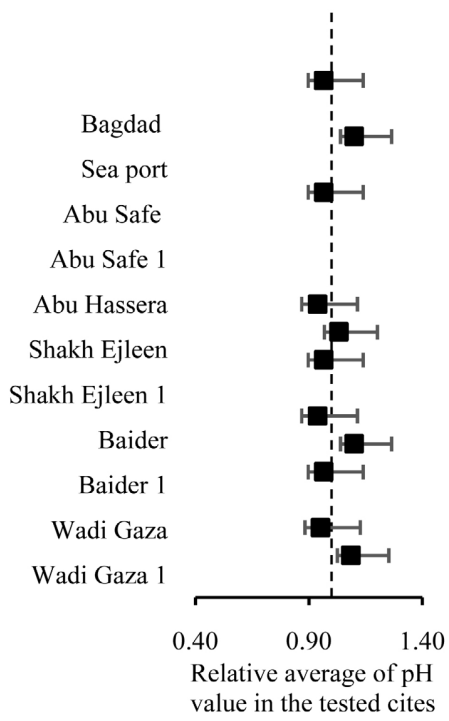

Figure 5. Forest plots of oxygen saturation \%, pH. And OC. Effect size represent the Reference avenge of oxygen $\mathrm{pH}$, and OC. Sites have size effect lower than the Ref Ave (1) are present on the left side whereas those in the right side have size effect larger than one indicating high extreme values. The points in contact with the dotted line have close value to reference average.

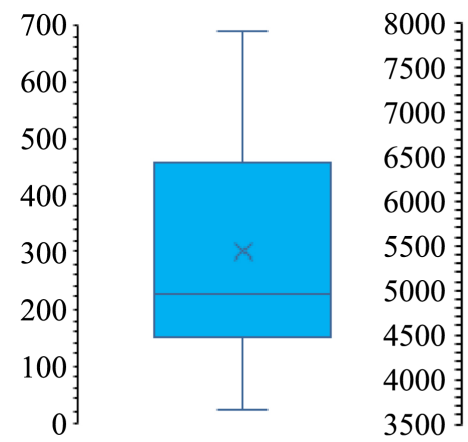

$\square$ Nitrate
3500

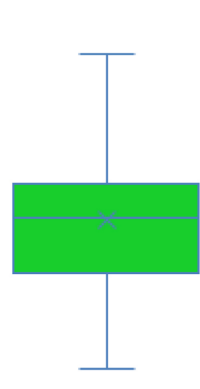

Sulfate

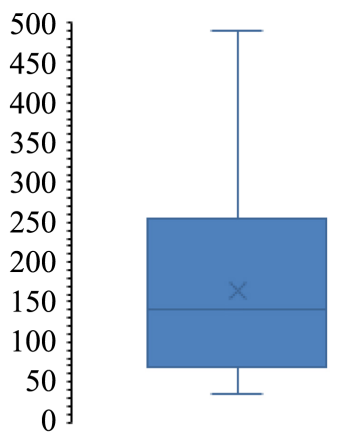

Phosphate

Figure 6. Boxplots of nitrate, sulfate and phosphate in the tested sites. 
Table 2. Nitrate, sulfate and phosphate profiles in some sites in Gaza.

\begin{tabular}{ccccccc}
\hline Parameter & Min. & Max. & Median & Average & SD & Range \\
\hline Nitrate & 22 & 690 & 225.5 & 299.8 & 204.07 & 668 \\
Sulfate & 4065 & 7608 & 5763 & 5736.9 & 817.14 & 3543 \\
Phosphate & 34 & 489 & 141 & 164.35 & 120.70 & 455 \\
\hline
\end{tabular}

Min., Max. and SD are minimum, maximum and standard deviation, respectively.

It can be seen that the minimum concentration of nitrate is $22 \mathrm{mg} / \mathrm{L}$, the maximum concentration is $690 \mathrm{mg} / \mathrm{l}$ with an average $299.8 \mathrm{mg} / \mathrm{L}$ and SD is 204.07. Sulfate profile is quite different, the minimum concentration is $4065 \mathrm{mg} / \mathrm{L}$, the maximum concentration $7608 \mathrm{mg} / \mathrm{l}$, with an average $5736.9 \mathrm{mg} / \mathrm{l}$ and SD 817.14. Phosphate profile is quite similar to nitrate, the minimum concentration is $34 \mathrm{mg} / \mathrm{L}$, the maximum concentration $489 \mathrm{mg} / \mathrm{L}$, with an average $164.35 \mathrm{mg} / \mathrm{L}$ and SD 120.70. The differences among sites can be visualized in Forest plots (Figure 7).

\section{Discussion}

The data in Figure 1 clearly show 14 tested sites distributed along the sea shore. Some of the sites change treated wastewater to the seashore and some other discharge untreated wastewater. The red color denoted the stations that discharge untreated wastewater. It is obvious that 6 pipe lines are discharging untreated wastewater. Additionally the stations are denoted also by geographical position system (GPS). Furthermore, the physical features of the sampling sites are shown in Figure 2. It can be seen that 8 sampling sites in the southern part of Gaza have sandy sea shore that enabled easy sampling. These sites are distributed from the south to the Seaport and included the following sites: Rafah, Khan Younis, Aquaculture, Dair Albalah S + N, Wadi Gaza, Baider, Shakh Ejleen, Seaport and its surroundings. In the other hand, the northern part of Gaza showed 8 sampling sites with a rocky shore that made the sampling process quite difficult. These sites are Abu saif, Abu Amera, Ebad Arahman, Baghdad, Abu Hassera, Khaldi, Mathaf and Sudania.

Furthermore, the photos in Figure 3 clearly show part of the field measurements and laboratory experiments.

Furthermore, the data in Table 1 clearly demonstrated statistical parameters of Temperature, EC, TDS, DO. pH and salinity. It can be seen that the range of all parameters are quite high except for $\mathrm{pH}$ and salinity. This suggests the buffering capacity of sea. However, the high range of Temperature (13.97) may be due to the fact that atmospheric temperature is changed during seasons resulting in change the temperature of sea water. This is due to the specific heat of water. Additionally, high range of EC and TDS appear from the influence of discharging wastewater directly to the seashore.

Moreover, the range of $\mathrm{DO}$ is 7.39 indicating a wide range of potential pollution. The minimum DO concentration is $2.09 \mathrm{mg} / \mathrm{L}$ indicating high pollution. 


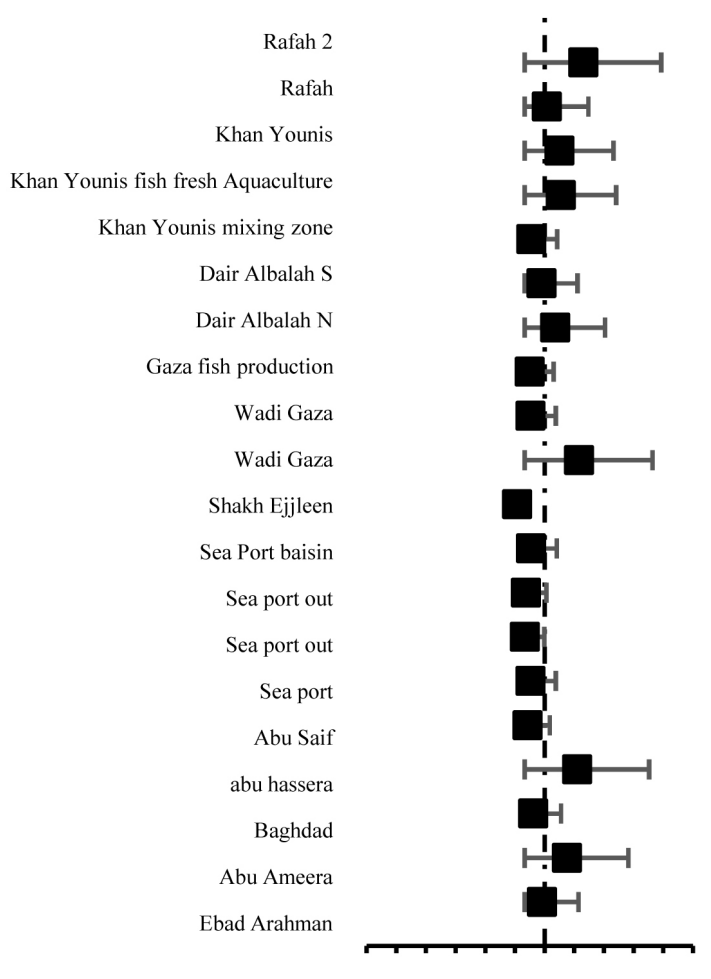

$\begin{array}{llllllllllll}-5 & -4 & -3 & -2 & -1 & 0 & 1 & 2 & 3 & 4 & 5 & 6\end{array}$

Relative average of nitrate conc

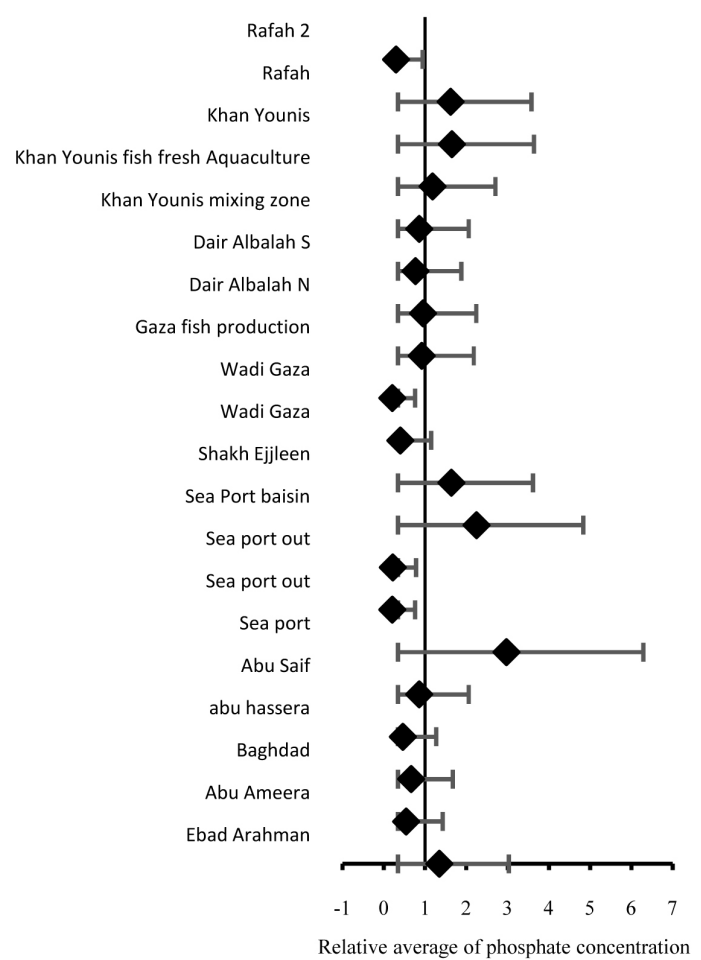

Relative average of phosphate concentration

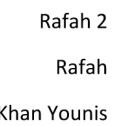

Khan Younis fish fresh Aquaculture

\section{Khan Younis mixing zone}

Dair Albalah S

Dair Albalah N

Gaza fish production

Wadi Gaza

Wadi Gaza

Shakh Ejjleen

Sea Port baisin

Sea port out

Sea port out

Sea port

Abu Saif

abu hassera

Baghdad

Abu Ameera

Ebad Arahman

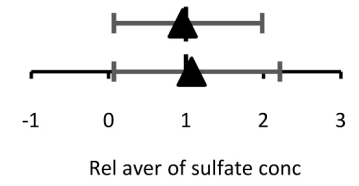

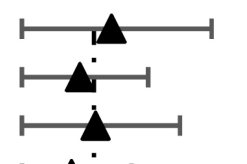

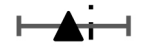
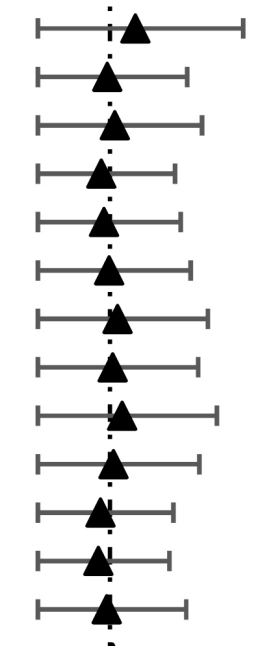

Figure 7. Forest plots of $\mathrm{NO}_{3}^{-}, \mathrm{SO}_{4}^{2-}$ and $\mathrm{PO}_{4}^{3-}$ concentrations in different sites. Reference avenge of nitrate, sulfate and phosphate are donated by the vertical line. Sites have size effect lower than the Ref Ave are present on the left side whereas those in the right side have size effect larger than one indicating high extreme values. The points in contact with the dotted line have close value to reference average. 


\subsection{Sources of EC and TDS in Aquatic Ecosystems}

So far, the source of EC and TDS appear from the continuous solubility of highly soluble salts and low soluble salts beside the fact that biodegradation of organic molecules may result in discharging cell minerals to sea water resulting in increasing the TDS. Since these molecules are ionized fragments, this may result in increasing the EC value of seawater.

So far salt in the sea may come from two sources: runoff from the land and openings in the seafloor. Rocks on land are the major source of salts dissolved in seawater. In some cases, rainwater is slightly acidic, so it erodes rocks. This may result in releasing ions that are carried away to streams and rivers that eventually feed into the ocean. Some of dissolved ions are consumed by aquatic organisms and removed from the water whereas other ions are not removed. This process may result in changing the EC value of the seawater. Furthermore, discharging treated and non-treated wastewater to the seawater may result in changing the $\mathrm{pH}$ value of the resulting precipitation of some divalent cations such as calcium, magnesium. Our explanation is in agreement with recent published work [31] [32] [33].

\subsection{Sources of Dissolved Oxygen in Aquatic Ecosystems}

\subsubsection{Atmospheric Sources}

Oxygen in the atmosphere may dissolve in water directly according to Ficks low, which depends on water temperature and oxygen partial pressure.

\subsubsection{Aquatic Photosynthesis}

Dissolved oxygen may be produced by the photosynthetic activity of blue green algae, cyanobacterial mats and aquatic plants (Equation (5)). This may be the major source of dissolve oxygen in the aquatic ecosystems. On the other hands, geochemical reactions may be additional source of dissolved oxygen in the ocean as shown the following equations

$$
\mathrm{HCO}_{3}^{-}+\mathrm{H}_{2} \mathrm{O}+\text { phytoplankton }+ \text { light } \rightarrow \mathrm{CH}_{2} \mathrm{O}+\mathrm{O}_{2}
$$

\subsection{Sources of Acidity in Aquatic Ecosystems}

\subsubsection{Direct Reaction of $\mathrm{CO}_{2}$}

Acidity in the aquatic ecosystem may occur due direct reaction of $\mathrm{CO}_{2}$ produced from respiration of aquatic organisms and water body as in Equation (5).

$$
\mathrm{CO}_{2}+\mathrm{H}_{2} \mathrm{O} \rightarrow \mathrm{H}^{+}+\mathrm{HCO}_{3}^{-}
$$

During the day the phytoplankton uses $\mathrm{HCO}_{3}^{-}$after converting it to $\mathrm{CO}_{2}$ inside their cell to form carbohydrate and oxygen throughout normal photosynthetic activity according to reaction (4). So far reaction Equation (4) and Equation (5) are responsible on increasing dissolved oxygen (Equation (4)) and increasing acidity of the ocean (Equation (5)).

In general, $\mathrm{CO}_{2}$ may be the key player in the ocean acidity. However, increasing the acidity of the ocean due to excess production of $\mathrm{H}^{+}$ion may deteriorate 
the oxygen production in the ocean due to inhibition of carbonic acid anhydrase that responsible in converting bicarbonate to $\mathrm{CO}_{2}$ inside the aquatic plant cells. Accordingly, partial or total inhibition of the photosynthetic activity may occur. Additionally, increasing ocean acidity may also harm the zooplankton directly due to dissolving shells and coral reeves according to Equation (6)

$$
\begin{gathered}
\mathrm{CaCO}_{3}(\text { sold })+\mathrm{H}^{+} \rightarrow \mathrm{HCaCO}_{3} \text { (soluble) } \\
\mathrm{HCO}_{3}^{-}+2 \mathrm{Ca}+\text { zooplankton (shell fish) } \rightarrow \mathrm{CaCO}_{3}
\end{gathered}
$$

Nevertheless, at optimal ocean $\mathrm{pH}$ the phytoplankton (Equation (4)) and the zooplankton (Equation (7)) may maintain the ocean acidity and oxygen production at the optimal levels. Our explanation and proposed reactions are in accordance of with McLaskey et al. [34] and El-Nahhal et al. [35] who found quite similar role of phytoplankton on the ocean. Additionally, Kohlbach et al. [36] reported the role of antarctic zooplankton species on the sea acidity. In contrast, ocean acidity caused certain damage to phyto-and zoo-plankton in the ocean [37].

\subsubsection{Biodegradation of Dissolved Organic Carbon}

Dissolved organic carbon such as carbohydrate like compounds (Equation (8)) and protein like compounds (Equation (9)) may undergo biochemical degradation reaction at different rates in aquatic ecosystem resulting in increasing the production of acidity $\left(\mathrm{H}^{+}\right)$.

$$
\begin{gathered}
\mathrm{C}_{6} \mathrm{H}_{12} \mathrm{O}_{6}+2 \mathrm{H}_{2} \mathrm{O} \rightarrow 2 \mathrm{CO}_{2}+2 \mathrm{CH}_{3} \mathrm{COO}^{-}+10 \mathrm{H}^{+}+9 \mathrm{e}^{-} \\
\mathrm{R}_{1} \mathrm{CH}\left(\mathrm{NH}_{2}\right) \mathrm{CONHCH}(\mathrm{COOH}) \mathrm{CH}(\mathrm{SH}) \mathrm{R}_{2}+3 \mathrm{H}_{2} \mathrm{O} \\
\rightarrow \mathrm{CO}_{2}+\mathrm{R}_{1} \mathrm{CH}_{2} \mathrm{COO}^{-}+\mathrm{R}_{2} \mathrm{CH}_{2} \mathrm{COO}^{-}+2 \mathrm{NH}_{3}+\mathrm{H}_{2} \mathrm{~S}+2 \mathrm{H}^{+} \\
2 \mathrm{CH}_{4}+3 \mathrm{H}_{2} \mathrm{O}_{2} \rightarrow 2 \mathrm{HCO}_{3}^{-}+12 \mathrm{H}^{+}+10 \mathrm{e}^{-}
\end{gathered}
$$

As obvious reactions (Equations (8)-(10)) produced considerable fraction of $\mathrm{H}^{+}$ion, hydrogen sulfide and ammonia, very soluble inorganic compounds. This is in agreement with previous reports [7] [35] [38] that revealed photo-degradation of DOM may produce even larger amounts of dissolved inorganic carbon in global freshwater and seawater. Produced hydrogen ion contributes to ocean acidity. The other ionic fragments $\left(\mathrm{CO}_{2}, \mathrm{H}_{2} \mathrm{~S}\right.$ and $\left.\mathrm{NH}_{3}\right)$ contribute to the geochemical cycles of carbon, nitrogen and sulfur.

\subsubsection{Oxidation of Inorganic Molecules}

Hydrogen sulfide, and ammonium hydroxide produced in Equations (8) and (9) may undergo oxidation reaction to produce $\mathrm{H}^{+}$ion that contribute to the $\mathrm{pH}$ changes in aquatic systems. These reactions may occur in surface water, photoactive zones as in river and oceans wastewater treatment plant specially oxidaton ponds,

$$
\begin{aligned}
& \mathrm{H}_{2} \mathrm{~S}+2 \mathrm{O}_{2} \rightarrow \mathrm{SO}_{4}^{2-}+2 \mathrm{H}^{+} \\
& \mathrm{H}_{2} \mathrm{O}+\mathrm{O}_{2}+\mathrm{NH}_{3} \rightarrow \mathrm{NO}_{3}^{-}+5 \mathrm{H}^{+}+4 \mathrm{e}^{-}
\end{aligned}
$$


It can be concluded most equations mentioned above produce hydrogen ion that contribute to $\mathrm{pH}$ changes. Additionally, reactions 4 and 5 maintain the acidity in river and sea water. Our explanation is in accordance with previous reports [35] [39] that reported the contribution of ammonia oxidation to chemoautotrophy in antarctic coastal waters. Additionally, Findlay et al. [40] reported the oxidation of hydrogen sulfide by phototrophic bacteria in the anoxic zone of the Chesapeake Bay.

On the other hand the reaction rates of dissolved organic compounds in water are affected by the intensity of sunlight. This is in accordance with Wang et al. [41] who found enhanced photochemical degradation of nebivolol in different natural organic matter solutions under simulated sunlight irradiation. Furthermore, Gornik, et al. [42] revealed the photodegradation of sertraline in aqueous systems due to exposure to sunlight. Moreover, Sun et al. [43] reported the degradation of N,N-diethyl-3-methylbenzamide and caffeine, by ultraviolet light and simulated sunlight in different water matrices.

Furthermore, exposure to sunlight may generate heat that enhances the chemical reactions in aquatic systems. Our explanation is in accordance with previous reports [44] [45] [46] [47] which revealed losing biological activities of pesticides due to direct exposure to sunlight and changes of maximum absorption due indirect exposure to sunlight. The data in Figure 4 clearly demonstrated the boxplots presentation of the measured physical parameters in all sites. For each tested parameter, the boxplot indicates homogeneity of the present results except some outliers. This suggests a precision of the experimental work. In contrast the presence of outliers may emerge from the fact the sea is an open ecosystem in continues dynamic movements that usually create changes in the tested parameters. Furthermore, the data in Figure 5, clearly demonstrated the Forest plots of the data in tested sites. It is obvious that most tested sites have nearly similar oxygen saturation \% except seaport and Abu amera have the lowest. Nevertheless, the differences are quite clear in $\mathrm{pH}$ values. It is obvious that Seaport, Baghdad and Wadi Gaza have the highest relative average of $\mathrm{pH}$. This is due to direct discharge of wastewater. The other sites have relative average less than one suggesting less pollution. Furthermore, relative average of organic carbon in marine sediment clearly shows that Waha, Abu Hassera, Shakh Ejleen and Wadi Gaza have the highest relative average indicating high organic contents. The explanation of these results is similar to that given above.

So far the concentration profile of nitrate, sulfate and phosphate are clearly presented in Figure 6 as boxplot. In the three tested parameters nitrate and phosphate have extreme low values and extreme high values suggesting the presence of outliers although they are not exist. This suggests extreme difference among sites due discharges of treated and untreated wastewater. The explanation of these results is that nitrate may be rapidly be uptake by aquatic phytoplankton, plants and weeds to for organic nitrogen that may be transported to protein in fish and zooplankton in the ocean. Additionally, nitrate may undergo photochemical degradation that result in a disappearance of considerable levels 


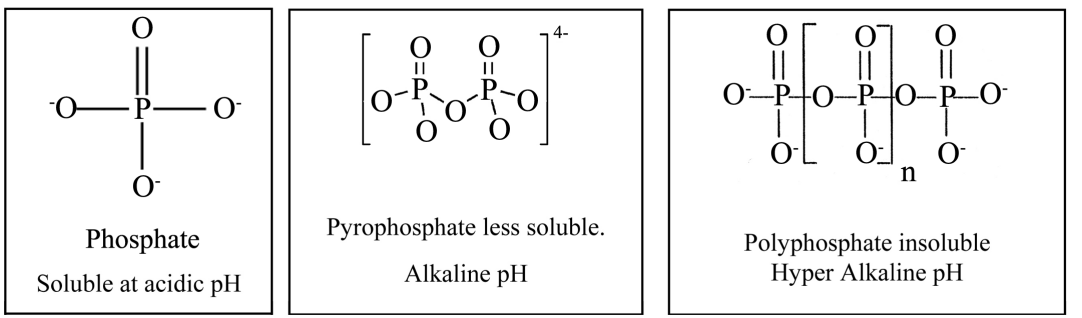

Figure 8. Molecular form of phosphate ion due to potential changes of $\mathrm{pH}$.

of nitrate from water. This is in agreement with Shaban et al. [48] who investigated the reduction of nitrate in seawater. In the other hand phosphate may disappear from sea water according to $\mathrm{pH}$ to the alkaline form instance at acidic $\mathrm{pH}$ as in the seashore or photoactive zone all phosphates present in the soluble form as phosphate whereas at alkaline $\mathrm{pH}$ it form pyrophosphate or poly phosphate molecules these molecules are insoluble and precipitate down to deep ocean which may converted to soluble fraction due to the acidity that may emerge from biodegration of organic and dead animals in the sea (Figure 8).

In the other hand sulfate concentration profile does not have extremely low value, suggesting homogeneity. So far, the homogeneity of sulfate concentration may emerge from the fact that sulfate is a highly soluble and active anion that can react with many species in sediments to form organic and/or inorganic salt. According to Equation (11) it is in a continuous formation in the ocean.

\section{Conclusion}

The rational of this work emerges from the fact that seawater is a natural resource that should be protected from pollution. The limitation of this study is that field measurement was not possible all the time because at rough sea it was not possible to collect samples from the rocky shore. Meanwhile, our investigations showed average and standard deviation of Temp of, $22.02^{\circ} \mathrm{C} \pm 4.1^{\circ} \mathrm{C}$, EC: $58.41 \pm 4.8 \mathrm{~ms} / \mathrm{cm}$; DO: $6.96 \pm 1.8 \mathrm{mg} / \mathrm{L} ; \mathrm{pH}: 7.69 \pm 0.37$; TDS: $30.51 \pm 3.29$ and salinity $4.39 \pm 0.12(\%)$; whereas, average and standard deviation of $\mathrm{NO}_{3}^{-}$: were $299.8 \pm 204.1 \mathrm{mg} / \mathrm{L} ; \mathrm{SO}_{4}^{2-}, 5736.9 \pm 817.1 ;$ and $\mathrm{PO}_{4}^{3-}: 164.35 \pm 120.7 \mathrm{mg} / \mathrm{L}$. Using Boxplot presentation of the results provides an over view on the homogeneity of data whereas using forest plots provides excellent tool to discriminate the difference among data. We recommend the use of boxplot and forest plots for presentation of results. Furthermore, our observations indicate the influence of wastewater discharge in changing the physicochemical properties sea water. The study recommends efficient treatment of wastewater and reuses it for agricultural purposes instead of discharging it in sea.

\section{Acknowledgements}

Special thanks go to de mission pour la coopération universitaire et scientifique, Consulat Général de France à Jerusalem, 3 Bibers street-Sheikh Jarrah|BP 182-Jerusalem 94109, for partial financial support. 


\section{Conflicts of Interest}

The author declare no competing interests

\section{References}

[1] Shriadah, M.A. and Emara, H.I. (1996) Heavy Metals (Iron, Manganese, Nickel, Cadmium, and Lead) in the Sediments from the Eastern Harbor and El-Mex Bay of Alexandria, Egypt. Proceedings of the Sixth International Conference on Environmental Protection, Alexandria, 21-23 May 1996, 916-927.

[2] Fahmy, M.A., Tayel, F.T. and Shriadah, M.A. (1997) Spatial and Seasonal Variations of Dissolved Trace Metals in Two Contaminated Basins of the Coastal Mediterranean Sea, Alexandria, Egypt. Bulletin Faculty of Science. Alexandria University, 37, 187-198.

[3] Masoud, M.S., Mahmoud, Th.H. and Abdel-halim, A.M. (2001) Chemical Studies of El-Mex Bay, Alexandria. Proceeding of the Second Conference and Exhibition for Life and Environment, Alexandria, 3-5 April 2001, 339-360.

[4] Samir, A.M. and El-Din, A.B. (2001) Benthic Foraminiferal Assemblages and Morphological Abnormalities as Pollution Proxies in Two Egyptian Bays. Marine Micropaleontology, 41, 193-227. https://doi.org/10.1016/S0377-8398(00)00061-X

[5] Labiosa, R.G., Arrigo, K.R., Genin, A., Monismith, S.G. and Dijken, G. (2003) The Interplay between Upwelling and Deep Convective Mixing in Determining the Seasonal Phytoplankton Dynamics in the Gulf of Aqaba: Evidence from SeaWiFS and MODIS. Limnology and Oceanography, 48, 2355-2368. https://doi.org/10.4319/lo.2003.48.6.2355

[6] El-Nahhal, Y. (2003) Adsorption Mechanism of Chloroacetanilide Herbicides to Modified Montmorillonite. Journal of Environmental Science and Health B, 38, 591-604. https://doi.org/10.1081/PFC-120023517

[7] El-Nahhal, I. and El-Nahhal, Y. (2020) Ecological Consequences of COVID-19 Outbreak. Journal of Water Science and Engineering, 1, 1-5.

[8] El-Nahhal, Y. and Radwan, A. (2013) Human Health Risks: Impact of Pesticide Application. Journal of Environment and Earth Science, 3, 199-209.

[9] El-Nahhal, Y., Lagaly, G. and Rabinovitz, O. (2005) Organo-Clay Formulations of Acetochlor: Effect of High Salt. Journal of Agricultural and Food Chemistry, 53, 1620 1624. https://doi.org/10.1021/jf040383a

[10] El-Nahhal, Y., Abadsa, M. and Affifi, S. (2013) Adsorption of Diuron and Linuron in Gaza Soils. American Journal of Analytical Chemistry, 4, 94-99. https://doi.org/10.4236/ajac.2013.47A013

[11] El-Nahhal, Y., Safi, M., Tubail, K. and Safi, J. (2013) Effect of Treated Wastewater Irrigation on Plant Growth and Soil Properties in Gaza Strip Palestine. American Journal of Plant Science, 4, 1736-1743. https://doi.org/10.4236/ajps.2013.49213

[12] Kinuthia, G., Ngure, V., Beti, D., Lugalia, R., Wangila, A. and Kamau, L. (2020) Levels of Heavy Metals in Wastewater and Soil Samples from Open Drainage Channels in Nairobi, Kenya: Community Health Implication. Scientific Reports, 10, Article No. 8434. https://doi.org/10.1038/s41598-020-65359-5

[13] El-Nahhal, Y. and El-Hams, S. (2017) Effects of Bromacil, Malathion and Thiabendazole on Cyanobacteria Mat Growth. International Journal of Applied Science Research and Review, 4, 1. https://doi.org/10.21767/2349-7238.100053

[14] El-Nahhal, Y. and Hams, S.H. (2020) Effects of Some Pesticides on Tilapia nilotica 
and Daphnia magna Life. IUG Journal of Natural Studies, 28, 28-37. https://doi.org/10.33976/IUGNS.28.1/2020/04

[15] El-Nahhal, Y. (2018) Toxicity of Some Aquatic Pollutants to Fish. Environmental Monitoring and Assessment, 190, 449. https://doi.org/10.1007/s10661-018-6830-0

[16] El-Nahhal, Y. and Hamdona, N. (2017) Adsorption, Leaching and Phytotoxicity of Some Herbicides as Single and Mixtures to Some Crops. Journal of the Association of Arab Universities for Basic and Applied Sciences, 22, 17-25. https://doi.org/10.1016/j.jaubas.2016.01.001

[17] El-Nahhal, I., Al-Najar, H. and El-Nahhal, Y. (2014) Cations and Anions in Sewage Sludge from Gaza Waste Water Treatment Plant. American Journal of Analytical Chemistry, 5, 655-665. https://doi.org/10.4236/ajac.2014.510073

[18] El-Nahhal, I., Redon, R., Raynaud, M., El-Nahhal, Y. and Mounier, S. (2021) Modelling of Impact of Presence/Absence of Suspended Particulate Organic Matter from River and Sea and Effluent Wastewater on Fluorescence Signal in the Coastal Area of Gapeau River. Environmental Science and Pollution Research (International), 28, 36707-36726. https://doi.org/10.1007/s11356-021-13265-2

[19] EL-Nahhal, I., Redon, R., Raynaud, M., EL-Nahhal, Y. and Mounier, S. (2020) Characterization of the Fate and Changes of Post-Irradiance Fluorescence Signal of Filtered Anthropogenic Effluent Dissolved Organic Matter from Wastewater Treatment Plant in the Coastal Zone of Gapeau River. Environmental Science and Pollution Research (International), 27, 23141-23158. https://doi.org/10.1007/s11356-020-08842-w

[20] El-Nahhal, H., Yassin, M., Alzaharna, M., El-Nahhal, I. and El-Nahhal, Y. (2021) Extraction Methods of Cyanotoxins Aqueous Media and Sediments. American Journal of Analytical Chemistry, 12, 311-323. https://doi.org/10.4236/ajac.2021.129019

[21] El-Nahhal, Y. and Alshanti, A. (2015) Toxicity of Single and Mixtures Antibiotics to Cyanobacteria. Environment and analytical Toxicology, 5, 1-8.

[22] Safi, J., El-Nahhal, Y. and Safi, M. (2018) Particle Size Distribution and Hydraulic Conductivity in Coastal Non-Agricultural Land in Gaza Coastal Plain. International Journal of Geosciences, 9, 619-633. https://doi.org/10.4236/ijg.2018.910037

[23] Heinze, S., Chen, Y., El-Nahhal, Y., Hadar, Y., Jung, R., Safi, J., Safi, M., Tarchitzky, J. and Marschner, B. (2014) Small Scale Stratification of Microbial Activity Parameters in Mediterranean Soils under Freshwater and Treated Wastewater Irrigation. Soil Biology and Biochemistry, 70, 193-204. https://doi.org/10.1016/j.soilbio.2013.12.023

[24] El-Nahhal, I., Al-Najar, H. and El-Nahhal, Y. (2014) Physicochemical Properties of Sewage Sludge from Gaza. International Journal of Geosciences, 5, 586-594. https://doi.org/10.4236/ijg.2014.56053

[25] El-Nahhal, Y. and Safi, J. (2004) Stability of an Organo Clay Complex: Effects of High Concentrations of Sodium Chloride. Applied Clay Science, 24, 129-136. https://doi.org/10.1016/j.clay.2003.01.002

[26] El-Nahhal, Y., Safi, M. and Safi, J. (2020) Salinity Profile in Coastal Non-Agricultural Land in Gaza. Environmental Science and Pollution Research (International), 27, 8783-8796. https://doi.org/10.1007/s11356-019-07514-8

[27] El-Nahhal, Y. (2018) Nitrate Residues in Fruits, Vegetables and Bread Samples and Their Health Consequences. Health, 10, 487-501. https://doi.org/10.4236/health.2018.104039

[28] Neal, C., Neal, M. and Wickham, H. (2000) Phosphate Measurement in Natural Waters: Two Examples of Analytical Problems Associated with Silica Interference 
Using Phosphomolybdic Acid Methodologies. The Science of the Total Environment, 251-252, 511-522. https://doi.org/10.1016/S0048-9697(00)00402-2

[29] El-Nahhal, I. and El-Nahhal, Y. (2021) Pesticide Residues in Drinking Water, Their Potential Risk to Human Health and Removal Options. Journal of Environmental Management, 299, Article ID: 113611. https://doi.org/10.1016/j.jenvman.2021.113611

[30] El-Nahhal, Y. (2020) Pesticide Residues in Honey and Their Potential Reproductive Toxicity. Science of the Total Environment, 741, Article ID: 139953. https://doi.org/10.1016/j.scitotenv.2020.139953

[31] NOAA (2021) Why Is the Ocean Salty? https://oceanservice.noaa.gov/facts/whysalty.html

[32] Saiki, T., Takizawa, Y., Miyahara, K. and Arima, M. (2020) Utilizing Conductivity of Seawater for Bioelectric Measurement of Fish. Scientific Reports, 10, Article No. 16363. https://doi.org/10.1038/s41598-020-73485-3

[33] Reddy, S.R.S., Karnena, M.K., Yalakala, S. and Saritha, V. (2020) Biological Treatability of Low Total Dissolved Solids (LTDS) Using SBR as a Pre-Treatment for Reverse Osmosis. Journal of Water Resource and Protection, 12, 135-154. https://doi.org/10.4236/jwarp.2020.122009

[34] McLaskey, A.K., Keister, J.E., Schoo, K.L., Olson, M.B. and Love, B.A. (2019) Direct and Indirect Effects of Elevated $\mathrm{CO}_{2}$ Are Revealed through Shifts in Phytoplankton, Copepod Development, and Fatty Acid Accumulation. PLoS ONE, 14, e0213931. https://doi.org/10.1371/journal.pone.0213931

[35] El-Nahhal, Z.Y., Al-Agha, R.M., El-Nahhal, Y.I., El Aila, N., El-Nahal, F. and Alhalabi, A.R. (2020) Electricity Generation from Animal Manure. Biomass and Bioenergy, 136, Article ID: 105531. https://doi.org/10.1016/j.biombioe.2020.105531

[36] Kohlbach, D., Graeve, M., Lange, B.A., David, C., Schaafsma, F.L., van Franeker, J.A., Vortkamp, M., Brandt, A. and Flores, H. (2018) Dependency of Antarctic Zooplankton Species on Ice Algae-Produced Carbon Suggests a Sea Ice-Driven Pelagic Ecosystem during Winter. Global Change Biology, 24, 4667-4681.

https://doi.org/10.1111/gcb.14392

[37] Cripps, G., Flynn, K.J. and Lindeque, P.K. (2016) Ocean Acidification Affects the Phyto-Zoo Plankton Trophic Transfer Efficiency. PLoS ONE, 11, e0151739. https://doi.org/10.1371/journal.pone.0151739

[38] Wang, W., Johnson, C.G., Takeda, K. and Zafiriou, O.C. (2009) Measuring the Photochemical Production of Carbon Dioxide from Marine Dissolved Organic Matter by Pool Isotope Exchange. Environmental Science \& Technology, 43, 8604-8609. https://doi.org/10.1021/es901543e

[39] Tolar, B.B., Ross, M.J., Wallsgrove, N.J., Liu, Q., Aluwihare, L.I., Popp, B.N. and Hollibaugh, J.T. (2016) Contribution of Ammonia Oxidation to Chemoautotrophy in Antarctic Coastal Waters. The ISME Journal, 10, 2605-2619. https://doi.org/10.1038/ismej.2016.61

[40] Findlay, A.J., Bennett, A.J., Hanson, T.E. and Luther, G.W. (2015) Light-Dependent Sulfide Oxidation in the Anoxic Zone of the Chesapeake Bay Can Be Explained by Small Populations of Phototrophic Bacteria. Applied and Environmental Microbiology, 81, 7560-7569. https://doi.org/10.1128/AEM.02062-15

[41] Wang, J., Wang, K., Guo, Y. and Niu, J. (2020) Photochemical Degradation of Nebivolol in Different Natural Organic Matter Solutions under Simulated Sunlight Irradiation: Kinetics, Mechanism and Degradation Pathway. Water Research, 173, Article ID: 115524. https://doi.org/10.1016/j.watres.2020.115524 
[42] Gornik, T., Vozic, A., Heath, E., Trontelj, J., Roskar, R., Zigon, D., Vione, D. and Kosjek, T. (2020) Determination and Photodegradation of Sertraline Residues in Aqueous Environment. Environmental Pollution (Barking, Essex: 1987), 256, Article ID: 113431. https://doi.org/10.1016/j.envpol.2019.113431

[43] Sun, P., Lee, W.N., Zhang, R. and Huang, C.H. (2016) Degradation of DEET and Caffeine under UV/Chlorine and Simulated Sunlight/Chlorine Conditions. Environmental Science \& Technology, 50, 13265-13273.

https://doi.org/10.1021/acs.est.6b02287

[44] El-Nahhal, Y., Nir, S., Margulies, L. and Rubin, B. (1999) Reduction of Photo-Degradation and Volatilization of Herbicides in Organo-Clay Formulations. Applied Clay Science, 14, 105-119. https://doi.org/10.1016/S0169-1317(98)00053-2

[45] El-Nahhal, Y., Undabeytia, T., Polubesova, T., Golda Mishael, Y., Nir, S. and Rubin, B. (2001) Organo-Clay Formulations of Pesticides: Reduced Leaching and Photodegradation. Applied Clay Science, 18, 309-326.

https://doi.org/10.1016/S0169-1317(01)00028-X

[46] El-Nahhal, Y., Awad, Y. and Safi, J. (2013) Bioremediation of Acetochlor in Soil and Water Systems by Cyanobacterial Mat. International Journal of Geosciences, 4, 880890. https://doi.org/10.4236/ijg.2013.45082

[47] Safi, J., Awad, Y. and El-Nahhal, Y. (2014) Bioremediation of Diuron in Soil Environment: Influence of Cyanobacterial Mat. American Journal of Plant Sciences, 5 , 1081-1089. https://doi.org/10.4236/ajps.2014.58120

[48] Shaban, A.Y., El Maradny, A.A. and Al Farawati, Kh.R. (2016) Photocatalytic Reduction of Nitrate in Seawater Using $\mathrm{C} / \mathrm{TiO}_{2}$ Nanoparticles. Journal of Photochemistry and Photobiology A: Chemistry, 328, 114-121. https://doi.org/10.1016/j.jphotochem.2016.05.018 